\title{
Effect of Reverse Bias on Dye-Sensitized Technology: Lessons for Application in PV-Integrated Textile Fabric Designs Useable in Wajir, Vihiga, Kitui and Kajiado Counties in Kenya
}

\author{
Raphael Venson Makokha Otakwa*, Herick Othieno and Andrew Odhiambo Oduor
}

\author{
Department of Physics \& Materials Science, School of Biological \& Physical Sciences, Maseno University, \\ PO Private Bag 40105, Maseno, Kenya
}

\begin{abstract}
This paper reports on the effect of reverse bias (RB) on dye-sensitized solar cells (DSSCs) that were investigated outdoor in Wajir ( $1^{\circ} 44^{\prime} 50^{\prime \prime}$ North, $40^{\circ} 4^{\prime} 8^{\prime \prime}$ East), Vihiga $\left(35^{\circ} 0^{\prime}\right.$ East, $0^{\circ} 15^{\prime}$ North), Kitui ( $3^{\circ} 0^{\prime}$ South, $37^{\circ} 50^{\prime}$ East) and Kajiado $\left(360^{\circ} 5^{\prime}\right.$ East, $30^{\circ} 0^{\prime}$ South) in Kenya. The DSSCs' J-V characteristics, namely, $V_{o c}, J_{s c}$, FF and $\eta$, were studied under varied RB potentials. This was achieved through partial, as well as complete shading of the DSSCs during their operation in the study sites, using a thick piece of black cloth, and measuring the obtaining J-V characteristics. Findings of the study reveal that subjecting the DSSC module that was investigated in Wajir to RB of between $1 \mathrm{~V}$ and $4 \mathrm{~V}$ triggered between $25.53 \%$ and $23.53 \%$ drop in the module's efficiency ( $\eta$ ), followed by its total breakdown thereafter. The modules studied in Vihiga, Kitui and Kajiado exhibited a similar trend, but with variations in $\eta$ under the different RB regimes. The DSSCs' breakdown under RB regimes of over half their voltage ratings could be attributed to the damaging of their dye constituents. These findings are important for context-informed DSSC dye choices, as well as DSSCintegrated designs that appeal to local cultural textile fabrics, like shawls, kanzu (long robes) and light coats that women and men dress in, respectively, in Wajir, and blankets that both men and women wrap around their shoulders in Kajiado, as well as in local architectures. The findings underscore the existence of vast prospects for localized industries that innovate in DSSC-integrated designs for local espousal. They could form foundations for programs that mentor people, especially children and youths at local levels to engage in climate change-mitigating enterprises.
\end{abstract}

Keywords: Dye sensitized, shading, textile fabrics, architecture.

\section{INTRODUCTION}

\subsection{Background}

Textile fabrics are attracting vast interest in the journey towards climate change mitigation and increased access to clean energy and its services. The interest has been inspired by the fact that climate change can only be mitigated, and global temperatures stabilized, when the total amount of carbon dioxide $\left(\mathrm{CO}_{2}\right)$ emitted is limited, such that the emissions are caused to eventually approach zero [1]. Options to slow down the emission of $\mathrm{CO}_{2}$ and other greenhouse gases (GHGs) through replacement of fossil fuel use with technologies that have less direct GHG emissions, such as renewable energy-based technologies, as well as through innovation of options that mitigate GHG emissions from buildings, transport, fabric, and the industrial sectors, are gaining significant traction [2-7]. These efforts are largely underpinned by the miniaturisation of electronic devices, and its expanding use in flexible gadgets. An example is the incorporation of sensors into wearable fabrics, which is currently enlisting predominant applications in medical, military, sports and leisure spheres [7]. Challenges

*Address correspondence to this author at the Department of Physics \& Materials Science, School of Biological \& Physical Sciences, Maseno University, PO Private Bag 40105, Maseno, Kenya; Tel: +254-722- 285-347; Fax: +254-057-351-221; E-mail: raphael.makokha@yahoo.com however exist as regards these applications. Most of the challenges stem from power management electronics in the systems, i.e., both energy harvesting and storage. This invites keen attention on the part of designers of photovoltaics (PVs), guided by emerging $\mathrm{PV}$ device-use questions, so as to augment the momenta in existing photovoltaic (PV)-integration.

\subsection{Questions for Designers of PV Integrated Systems}

For flexible PV systems, an important question facing designers revolves around the characteristics of their components when operating under the five critical factors that influence their performance, namely, irradiance, temperature, shading, soiling and snow. Ostfeld and Arias opine that keenness on these characteristics, especially for thin-film technologies, is critical to making fabrication decisions for effective PVintegrated textile fabrics [8]. The study reported in this paper focused on textile PV integration because textiles provide a huge opportunity for contribution by all individuals in enhancing access to clean energy, and individual contributions to climate change mitigation. Gadgets that are frequently used by undividuals, including mobile telephones, could be charged, as they go about their day-to-day routines, by means of PVs integrated in their clothing. Wajir, Vihiga, Kitui, and Kajiado were chosen as study areas because 
they represent areas in Kenya that are reported to be acutely deprived of electricity and its modern services [9]. For effective PV integration, context-informed characteristics of the system components need to be known prior to designing them so as to minimize any complexities that may arise in the processes, as well as maximize design freedoms for every component of the system. In this paper, therefore, we report on the findings of the performance characterisation of dyesensitized solar cells (DSSCs) under various shading regimes as the devices operated outdoor under the micro-climatic conditions of Wajir, Vihiga, Kitui and Kajiado Counties in Kenya.

\section{LITERATURE REVIEW}

\subsection{Reverse Biasing of Solar Cells}

When solar cells are reverse biased, they consume the power generated by their neighbor cells, become hot, and are not able to function properly [10]. Reverse bias (RB) conditions emanate from voltages across PV cells opposing the open circuit potentials of the cells. The ability of a PV device to withstand effects of periodic hot-spot heating that occur when cells are operated under RB is one of the device's quality factors that are usually verified under the qualification testing by the International Electrotechnical Commission (IEC) [11]. The concept of RB is very applicable in real-life situations: a multi-cell module could, in the course of its operation under 'real world' operating conditions, have one or more of its cells partially or completely shaded. When cells in the module's series connection are partially shaded, current passes them in RB, with the shaded cells experiencing voltages coming from the lit cells in the module but in reverse direction. The reverse voltage could adversely modify or damage the cell if the cell is not properly protected. This is because the cell causes hot-spot heating, whose extent is normally PV material-specific. Indeed, studies have linked locally concentrated shunt defects to non-uniformities in PV materials [12]. The extent of the defects correlates with the slope of the reverse current density-voltage $(\mathrm{J}-\mathrm{V})$ characteristics [13]. Further to the five critical factors that influence PV system performances, namely, irradiance, temperature, shading, soiling and snow, therefore, the type of solar PV cell also influences the extent of the cell's $\mathrm{J}-\mathrm{V}$ hysteresis while operating under RB. These hysteretic effects pose a substantial challenge to efforts on PV technology integration in gadgets. They however provide useful information regarding the transport and polarization mechanisms that could be harnessed in practical PV-integrated innovations.

\subsection{Reverse Biasing DSSCs - Key Challenges}

Kern et al. have reported that reverse biasing a DSSC is not perilous to its stability [14]. Other researchers have reported that the reaction rate of the DSSC that they investigated was less than that of the cell before being subjected to RB [15]. This finding was realized upon applying the reaction rate experimental data of the DSSC that was investigated to the simplified Butler-Volmer equation [16]:

$$
\mathrm{J}(\mathrm{V})=\mathrm{J}_{\mathrm{o}}\left(\exp \left(\beta \frac{\mathrm{qv}}{\mathrm{kT}}\right)\right)
$$

where $\left(\exp \left(\beta \frac{\mathrm{qv}}{\mathrm{kT}}\right)\right) \sim$ zero for $\mathrm{V}<0$ and, $\mathrm{J}_{0}, \beta, \mathrm{k}, \mathrm{T}$, and q represent the exchange current density (which is indicative of the rate of oxidation or reduction at an equilibrium electrode, the symmetry factor, Boltzman Constant, absolute temperature, andthe elementary charge.

The cell was also found to exhibit loss in its efficiency (n) [15]. The researchers attributed the loss to depletion of the N-C-S vibration band in the cell's dye, as well as increased charge transfer resistance at the counter electrode (CE) [15]. Increased resistance at the CE has been associated with decreased catalytic activity of the Platinum $(\mathrm{Pt})$ [17]. This is because oxidation of the $\mathrm{Pt}$ at the CE normally acts as a catalyst for regeneration of the lodide. The study also found that the morphology of the titanium dioxide $\left(\mathrm{TiO}_{2}\right)$ film on the glass substrate did not change when the cell was subjected to RB [15]. In another study, it was established that net current in DSSCs is negatively affected by shading [18]. Collectively, therefore, these studies highlight the import of further RB-related studies. This is because some report that DSSCs are not affected by RB while others signal departures from this finding. It was postulated, as part of this study that the variances could be due to dissimilarities in study contexts. Indeed, Otakwa et al. have demonstrated why area-specific performance investigation of DSSCs is imperative, as it provides credible data and information for use by designers of DSSC systems for use in those contexts [19]. The foregoing, therefore, motivated this study, and triggered the quest to establish how reverse biasing DSSCs would influence their performance in Wajir, Vihiga, Kitui and Kajiado Counties in Kenya. Findings of the study are expected 
to trigger DSSC application in textile fabrics and building integrated PVs (BIPVs) towards fully energy independent individuals, as well as net zero energy (NZE) built-environments in the study areas and areas with similar micro-climates.

\section{RESEARCH METHODOLOGY}

\subsection{Introduction}

This study adopted an exploratory research design. Four DSSC modules, each having 8 series-connected cells, and of typical open circuit voltage and short circuit current ratings of $8.0 \mathrm{~V}$ and $140 \mathrm{~mA}$, respectively, were procured, tested, and one of each deployed and set up in one of the study locations, namely, Wajir

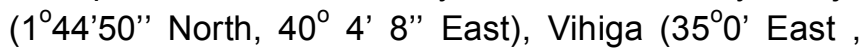
$0^{\circ} 15^{\prime}$ North), Kitui ( $3^{\circ} 0^{\prime}$ South, $37^{\circ} 50^{\prime}$ East) and Kajiado $\left(360^{\circ} 5^{\prime}\right.$ East, $30^{\circ} 0^{\prime}$ South) in Kenya. The locations were randomly sampled from those reported as having a multi-dimensional energy poverty index (MEPI) of below 0.3 , which is the cut-off point that was associated with acute deprivation from electricity and its associated clean energy services [9]. The locations, therefore, fairly represent areas in Kenya whose residents could benefit notably from DSSCs owing to their promise of affordability underpinned by their use of locally available raw materials, bottom-up fabrication possibilities, etc.

\subsection{About the Study Locations}

Wajir is located in the former North-Eastern province in Kenya. 98.4\% of households in the area depend on wood-fuel, i.e., firewood and charcoal, for cooking, $31.5 \%$ on kerosene for lighting and, $96.6 \%$ on traditional stone-fire for cooking [20]. Solar energy accounts for a mere $0.2 \%$ of energy source in the county, is limited to schools and health facilities and, is out of reach for majority of the households [21]. 75.9\% of houses in the county are grass-straw walled, with grass-thatched houses constituting $86.2 \%$ of the houses [20]. These beckon innovations toward affordable BIPVs. Regarding climate change, its effects, including unpredictable rainfall, frequent and prolonged droughts, unpredictable floods, and extreme weather conditions, are widespread in Wajir County. The County experiences annual relative humidity of $61.8 \%$; ranging from $56 \%$ in February to $60 \%$ in June [20].

Majority of residents of the county are pastoralists, for whom textile fabric integrated photovoltaics could be valuable toward lighting and charging their regularly used electronic devices, like mobile telephones. Women clothing include shawls, buibui (Swahili word for Islamic women robes), and headgears that are often largely decorated with ornaments. Men, on the other hand, wear clothing that mainly comprises of kanzu (Swahili word for a robe mainly worn by Muslims), and light coats.

Vihiga, another study location of this study, is located in the western part of Kenya, within the Lake Victoria Basin. The Equator cuts across southern parts of Vihiga County. A high equatorial climate is experienced in the County, with well-distributed rainfall throughout the year and, an average precipitation of $1900 \mathrm{~mm}$. Temperatures in the County range between $14^{\circ} \mathrm{C}$ and $32^{\circ} \mathrm{C}$ [22]. Regarding population, the 2009 Kenya Population and Housing Census (KPHC) put Vihiga's population at 554,$662 ; 47.8 \%$ male and $52.2 \%$ female [21].

The population density in the County is 1,044 persons per $\mathrm{Km}^{2}$ [21]. Access to electricity by urban households is $10.8 \%$, while rural access is a mere $5.3 \%$ [23]. The fuel that is mainly used for cooking in the County is firewood, i.e., used by $84.8 \%$ of the population, while $88.7 \%$ of the population uses paraffin for lighting [23]. These precipitate health concerns, whose burden is mostly borne by women and children. All trading centres in Vihiga County either lack electricity or experience frequent fluctuations in electricity supply, which slows economic activity and hence, livelihoods opportunities in the County. Vihiga, thence, has ample drivers for modelling widespread espousal of the dye-sensitized technology.

Kitui, another study location of this study, has both arid and semi-arid topographies. It is both hot and dry, with erratic and unreliable rainfall patterns and, experiences high temperatures that range between $14^{\circ} \mathrm{C}$ and $34^{\circ} \mathrm{C}$ [24]. The main sources of energy in the County are fuel-wood, mainly in the form of firewood and charcoal. Only $3.8 \%$ of households in the County, including less than $1 \%$ in rural households, are connected to the national electricity grid, and less than half of the trading centres connected to electricity [24]. The County is significant in the arena of climate change triggering energy sources, owing to its endowment with huge deposits of coal in the Mui Coal Basin.

Kajiado, which was the fourth study location of this study, has a bi-modal rainfall pattern and temperatures that vary both with altitude and season. The highest 
temperatures, of about $34^{\circ} \mathrm{C}$, are normally experienced around Lake Magadi, while the lowest, of about $10^{\circ} \mathrm{C}$, are experienced at Loitoktok [25]. Kajiado's main energy sources are firewood, charcoal, solar and petroleum fuels, with only $39.8 \%$ of households in the County connected to electricity from the national grid [25]. Unreliability in power supply is however perennial among those connected to grid electricity.

Regarding housing, a marked disparity exists among urban, peri-urban and rural settlements. In urban centres, for example, both high-end and sprawling informal settlements exist. Peri-urban areas, on the other hand, mainly have permanent and semipermanent housing. Semi-permanent houses and manyattas dominate the rural parts of Kajiado. Residents of the County are largely pastoralists, and often trek for long distances while covered in blankets or shukas (specially designed thick piece of cloth that shields their users from extreme weather conditions, like winds and cold).

\subsection{J-V Characterisation}

J-V characteristics, namely, short-circuit current density $\left(\mathrm{J}_{\mathrm{sc}}\right)$, open circuit voltage $\left(\mathrm{V}_{\mathrm{oc}}\right)$, fill factor (FF) and efficiency $(\eta)$ were initially established under this study with none of the modules' cells shaded. These characteristics were evaluated using the equations [26]:

$J(V)=J_{L}-J_{S} \exp \left[\frac{V+R_{S} J}{m V_{T}}\right]-\sigma V$

where $\mathrm{J}, \mathrm{J}_{\mathrm{L}}, \mathrm{J}_{\mathrm{s}}, \mathrm{V}, \mathrm{m}, \mathrm{V}_{\mathrm{T}}, \mathrm{R}_{\mathrm{s}}$ and $\sigma$ represent the ideal current density, current density from the source, saturation current density, voltage across the PV perminals, the ideality factor, thermal voltage, series resistance and shunt conductance, respectively,

$\mathrm{V}_{\mathrm{OC}}=\mathrm{mV}_{\mathrm{T}} \ln \frac{\mathrm{J}_{\mathrm{ph}}}{\mathrm{J}_{\mathrm{S}}}$

where $J_{p h}, \quad J_{s}, \quad V_{o c}, m$ and $V_{T}$ represent the photogenerated current density, saturation current density, open circuit voltage, the ideality factor, and thermal voltage, respectively,

$\mathrm{FF}=\frac{\mathrm{P}_{\mathrm{m}}}{\mathrm{V}_{\mathrm{OC}} \mathrm{J}_{\mathrm{SC}}}=\frac{\mathrm{J}_{\mathrm{mp}} \mathrm{V}_{\mathrm{mp}}}{\mathrm{V}_{\mathrm{OC}} \mathrm{J}_{\mathrm{SC}}}$

where $F F, P_{m}, V_{o c},, J_{s c}, J_{m p}$ and $V_{m p}$ represent the fill factor, maximum power density, open circuit voltage, short circuit current density, maximum power current density, and maximum power voltage, respectively, and

$\eta=\frac{P_{m}}{P_{\text {in }}}=\frac{J_{\text {mp }} V_{\text {mp }}}{P_{\text {in }}}=\frac{V_{\mathrm{OC}} J_{\text {SC }} F F}{P_{\text {in }}} \times 100 \%$

where $\eta, P_{m}, V_{m p}, V_{o c}, J_{s c}, F F$, and $P_{\text {in }}$ represent the efficiency, maximum power density, current density at maximum power point, voltage at maximum power point, open circuit voltage, short circuit current density, fill factor, and the power of the incident light, respectively.

\subsection{Incremental Module Shading}

Performance studies for the DSSC modules were undertaken with the cells being incrementally shaded, on consecutive days, until no further performance data could be registered under the shading. Measurements were taken at intervals of 30 minutes; between 0600 and 0630 hours, 0800 and 0830 hours, 1000 and 1030 hours, 1200 and 1230 hours, 1500 and 1530 hours and 1800 and 1830 hours.

After investigation of the modules under a given shading regime, they were disengaged from the circuits overnight, and connected the following day for investigation under a higher RB regime. Each day's study of the DSSC module performances was preceded by an investigation with none of the cells shaded.

The set-up of the experiment comprised of an adjustable aluminum stand that was fabricated in Luanda Town, Vihiga County, on which the module was fixed during characterization; a Kipp \& Zonen CMP3 pyranometer that was procured from Kipp \& Zonen company, and which was used for measuring irradiance intensity; a data logger that was procured from National Instruments, which was used for capturing data relating to irradiance intensity; a fluke digital thermocouple thermometer that was procured from National Instruments, and which was used for monitoring module surface temperatures; a decade resistance that was procured from SparkFun Electronics, and which was used for monitoring load resistance; two digital 87 multimeters that were procured from Texas Instruments, and which were used for photocurrent measurements; and a digital fluke 73III multimeter that was procured from Texas Instruments, and which was used for voltage measurements. Figure 1 is a schematic representation of how the experiment was set up in each of the four study sites in the study locations. 


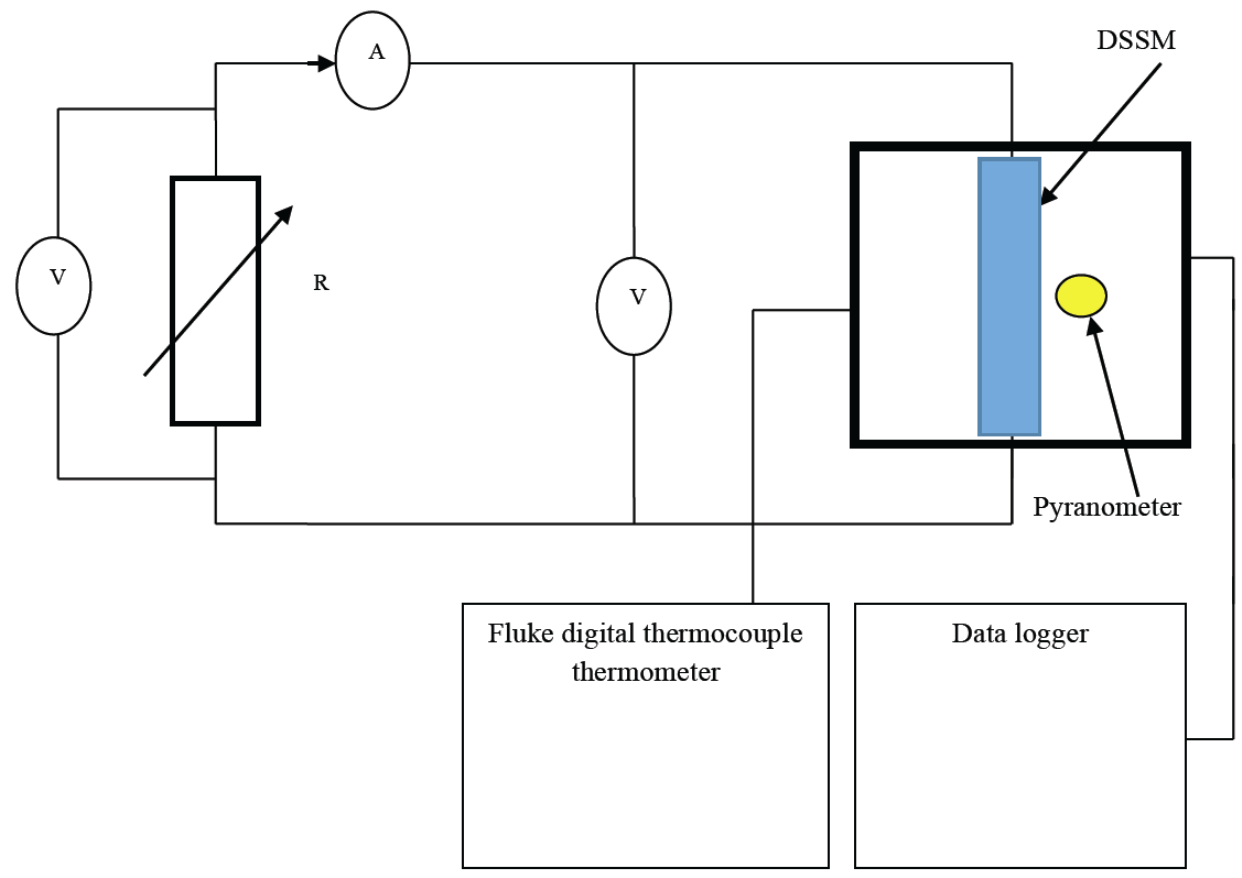

Figure 1: Schematic diagram of the experiment set-up.

\section{FINDINGS AND DISCUSSION}

Tables 1 to 18 present data findings of the study on the DSSC modules investigated for their performances at different times of the day in study locations in Wajir, Vihiga, Kitui and Kajiado counties in Kenya, under various RB potentials.

\subsection{DSSC Module Performances in Wajir}

$\mathrm{RB}$ of $1 \mathrm{~V}$ and $2 \mathrm{~V}$ caused a $25.53 \%$ and $36.19 \%$ loss in $\eta$, respectively; a $41.8 \%$ reduction between the potentials. Increasing the number of cells under RB, thus caused more than proportionate limiting effect on the module's $\eta$. Shading 3 cells caused $27.52 \% \eta$ loss , while $4 \mathrm{~V}$ RB led to $23.53 \% \eta$ loss. When half of the cells were shaded, the $\eta$ did not recover, and collapsed when over half were shaded.

\subsection{DSSC Module Performances in Vihiga}

The $\eta$ of the DSSC module investigated in Vihiga reduced by $24.19 \%$ when 1 of its cells was shaded, compared to when none of its cells had been shaded. Subjecting it to RB potentials of $2 \mathrm{~V}, 3 \mathrm{~V}, 4 \mathrm{~V}$ and $5 \mathrm{~V}$ resulted in a $45.59 \%, 51.38 \%, 52.63 \%$ and $63.16 \%$, loss in $\eta$, respectively; a demonstration of the negative effect on the module's $\eta$ increases as more of its cells are subjected to RB, but at disproportionate rates. After subjection to $5 \mathrm{~V} R B$, the module's $\mathrm{J}-\mathrm{V}$ characteristics

Table 1: J-V Data for the DSSC Module Studied in Wajir, with 1 of its Cells Shaded. The Shaded Column has Data Obtained within 0600-0630 Hours Prior to the Shading. The Irradiance during the Period was $2.50 \times 10^{-04} \mathrm{Wcm}^{-2}$

\begin{tabular}{|c|c|c|c|c|c|c|c|}
\hline Time (Hours) & $0600-0630$ & $0600-0630$ & $0800-0830$ & $1000-1030$ & $1200-1230$ & $1500-1530$ & $1800-1830$ \\
\hline$V_{o c}(V)$ & 7.02 & 6.82 & 7.05 & 7.16 & 7.21 & 7.18 & 6.89 \\
\hline $\mathrm{J}_{\mathrm{sc}}\left(\mathrm{mAcm} \mathrm{Ac}^{-2}\right)$ & $1.37 \times 10^{-4}$ & $1.07 \times 10^{-4}$ & $1.27 \times 10^{-4}$ & $3.74 \times 10^{-4}$ & $5.31 \times 10^{-4}$ & $3.26 \times 10^{-4}$ & $1.05 \times 10^{-4}$ \\
\hline $\mathrm{V}_{\mathrm{oc}} \mathrm{J}_{\mathrm{sc}}\left(\mathrm{VmAcm}^{-2}\right)$ & $9.62 \times 10^{-4}$ & $7.30 \times 10^{-4}$ & $8.95 \times 10^{-4}$ & $2.68 \times 10^{-3}$ & $3.83 \times 10^{-3}$ & $2.34 \times 10^{-3}$ & $7.23 \times 10^{-4}$ \\
\hline $\mathrm{V}_{\mathrm{mp}}(\mathrm{V})$ & 6.80 & 5.78 & 5.87 & 5.95 & 6.16 & 5.97 & 5.81 \\
\hline $\mathrm{J}_{\mathrm{mp}}\left(\mathrm{mAcm}{ }^{-2}\right)$ & $1.05 \times 10^{-4}$ & $9.07 \times 10^{-5}$ & $1.06 \times 10^{-4}$ & $2.98 \times 10^{-4}$ & $3.18 \times 10^{-4}$ & $2.24 \times 10^{-4}$ & $9.32 \times 10^{-5}$ \\
\hline$V_{m p} J_{m p}\left(V m A c m^{-2}\right)$ & $7.14 \times 10^{-4}$ & $5.24 \times 10^{-4}$ & $6.22 \times 10^{-4}$ & $1.77 \times 10^{-3}$ & $1.96 \times 10^{-3}$ & $1.34 \times 10^{-3}$ & $5.41 \times 10^{-4}$ \\
\hline FF & 0.74 & 0.72 & 0.69 & 0.66 & 0.51 & 0.57 & 0.75 \\
\hline$P_{\text {in }}\left(W_{c m}^{-2}\right)$ & $2.50 \times 10^{-4}$ & $2.18 \times 10^{-4}$ & $4.48 \times 10^{-4}$ & $6.77 \times 10^{-4}$ & $9.88 \times 10^{-4}$ & $8.40 \times 10^{-4}$ & $2.50 \times 10^{-4}$ \\
\hline$\eta(\%)$ & 2.85 & 2.41 & 1.38 & 2.61 & 1.98 & 1.59 & 2.17 \\
\hline
\end{tabular}


Table 2: J-V Data for the DSSC Module Studied in Wajir, with 2 of its Cells Shaded. The Shaded Column has Data Obtained within 0600-0630 Hours Before the Shading. The Irradiance during the Period was $2.18 \times 10^{-04} \mathrm{Wcm}^{-2}$

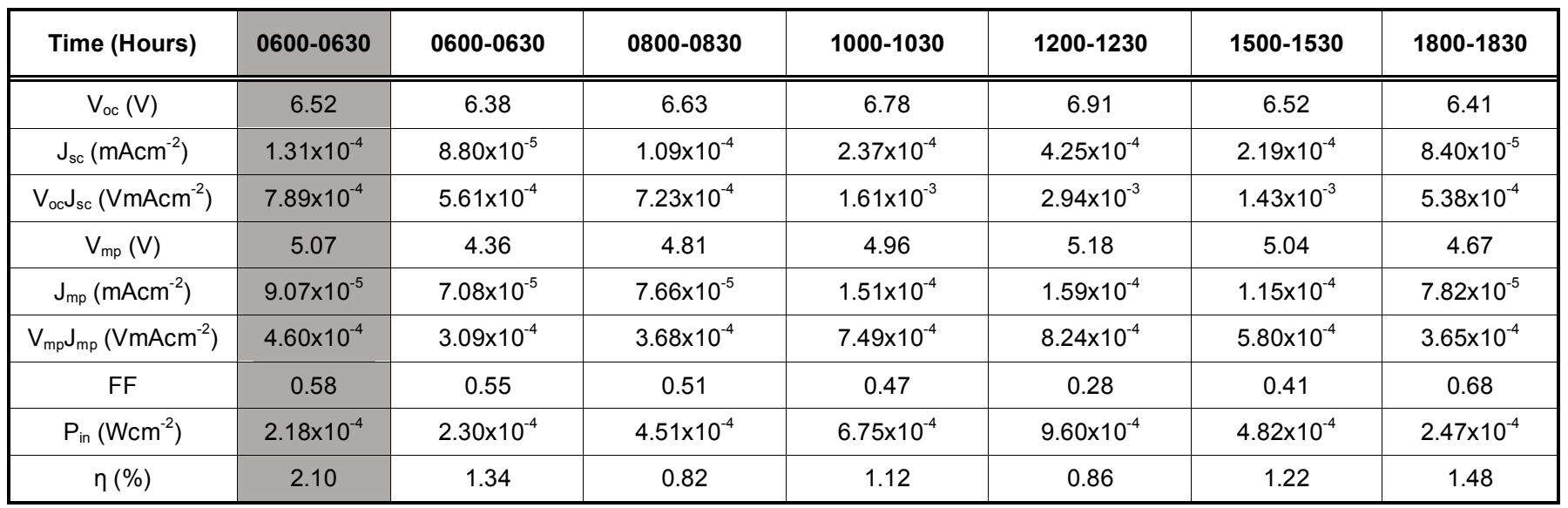

Table 3: J-V Data for the DSSC Module Studied in Wajir, with 3 of its Cells Shaded. The Shaded Column has Data Obtained within 0600-0630 Hours Before the Shading. The Irradiance during the Period was $2.30 \times 10^{-04} \mathrm{Wcm}^{-2}$

\begin{tabular}{|c|c|c|c|c|c|c|c|}
\hline Time (Hours) & $\mathbf{0 6 0 0 - 0 6 3 0}$ & $\mathbf{0 6 0 0 - 0 6 3 0}$ & $\mathbf{0 8 0 0 - 0 8 3 0}$ & $\mathbf{1 0 0 0 - 1 0 3 0}$ & $\mathbf{1 2 0 0 - 1 2 3 0}$ & $\mathbf{1 5 0 0 - 1 5 3 0}$ & $\mathbf{1 8 0 0 - 1 8 3 0}$ \\
\hline \hline $\mathrm{V}_{\mathrm{oc}}(\mathrm{V})$ & 5.45 & 5.31 & 5.53 & 5.65 & 5.76 & 5.43 \\
\hline $\mathrm{J}_{\mathrm{sc}}\left(\mathrm{mAcm}^{-2}\right)$ & $8.75 \times 10^{-5}$ & $7.92 \times 10^{-5}$ & $1.17 \times 10^{-4}$ & $1.98 \times 10^{-4}$ & $3.54 \times 10^{-4}$ & $1.99 \times 10^{-4}$ & $7.01 \times 10^{-5}$ \\
\hline $\mathrm{V}_{\mathrm{oc}} \mathrm{J}_{\mathrm{sc}}\left(\mathrm{VmAcm}^{-2}\right)$ & $4.75 \times 10^{-4}$ & $4.21 \times 10^{-4}$ & $6.47 \times 10^{-4}$ & $1.12 \times 10^{-3}$ & $1.99 \times 10^{-3}$ & $1.08 \times 10^{-3}$ & $3.74 \times 10^{-4}$ \\
\hline $\mathrm{V}_{\mathrm{mp}}(\mathrm{V})$ & 4.08 & 3.05 & 3.61 & 4.05 & 4.32 & 4.20 \\
\hline $\mathrm{J}_{\mathrm{mp}}\left(\mathrm{mAcm}^{-2}\right)$ & $6.13 \times 10^{-5}$ & $6.05 \times 10^{-4}$ & $7.29 \times 10^{-5}$ & $1.03 \times 10^{-4}$ & $1.03 \times 10^{-4}$ & $1.34 \times 10^{-4}$ & $6.12 \times 10^{-5}$ \\
\hline $\mathrm{V}_{\mathrm{mp}} \mathrm{J}_{\mathrm{mp}}\left(\mathrm{VmAcm}{ }^{-2}\right)$ & $2.50 \times 10^{-4}$ & $1.85 \times 10^{-4}$ & $2.63 \times 10^{-4}$ & $4.17 \times 10^{-4}$ & $4.45 \times 10^{-4}$ & $5.63 \times 10^{-4}$ & $2.28 \times 10^{-4}$ \\
\hline $\mathrm{FF}$ & 0.53 & 0.43 & 0.41 & 0.37 & 0.22 & 0.52 & 0.64 \\
\hline $\mathrm{P}_{\mathrm{in}}\left(\mathrm{Wcm}{ }^{-2}\right)$ & $2.30 \times 10^{-4}$ & $2.30 \times 10^{-4}$ & $4.51 \times 10^{-4}$ & $6.75 \times 10^{-4}$ & $9.60 \times 10^{-4}$ & $8.10 \times 10^{-4}$ & $2.47 \times 10^{-4}$ \\
\hline$\eta(\%)$ & 1.09 & 0.79 & 0.59 & 0.61 & 0.46 & 0.69 & 0.97 \\
\hline
\end{tabular}

Table 4: J-V Data for the DSSC Module Studied in Wajir, with 4 of its Cells Shaded. The Shaded Column has Data Obtained within 0600-0630 Hours Before the Shading. The Irradiance during the Period was $2.32 \times 10^{-04} \mathrm{Wcm}^{-2}$

\begin{tabular}{|c|c|c|c|c|c|c|c|}
\hline Time (Hours) & $\mathbf{0 6 0 0 - 0 6 3 0}$ & $\mathbf{0 6 0 0 - 0 6 3 0}$ & $\mathbf{0 8 0 0 - 0 8 3 0}$ & $\mathbf{1 0 0 0 - 1 0 3 0}$ & $\mathbf{1 2 0 0 - 1 2 3 0}$ & $\mathbf{1 5 0 0 - 1 5 3 0}$ & $\mathbf{1 8 0 0 - 1 8 3 0}$ \\
\hline \hline $\mathrm{V}_{\mathrm{oc}}(\mathrm{V})$ & 3.27 & 2.97 & 3.10 & 3.21 & 3.30 & 3.07 \\
\hline $\mathrm{J}_{\mathrm{sc}}\left(\mathrm{mAcm}{ }^{-2}\right)$ & $5.43 \times 10^{-5}$ & $5.15 \times 10^{-5}$ & $6.80 \times 10^{-5}$ & $7.19 \times 10^{-5}$ & $7.78 \times 10^{-5}$ & $6.97 \times 10^{-5}$ & $2.82 \times 10^{-5}$ \\
\hline $\mathrm{V}_{\mathrm{oc}} \mathrm{J}_{\mathrm{sc}}\left(\mathrm{VmAcm}{ }^{-2}\right)$ & $1.76 \times 10^{-4}$ & $1.53 \times 10^{-4}$ & $2.11 \times 10^{-4}$ & $2.31 \times 10^{-4}$ & $2.57 \times 10^{-4}$ & $2.14 \times 10^{-4}$ & $8.43 \times 10^{-5}$ \\
\hline $\mathrm{V}_{\mathrm{mp}}(\mathrm{V})$ & 1.47 & 1.21 & 1.45 & 2.47 & 2.59 & 2.42 \\
\hline $\mathrm{J}_{\mathrm{mp}}\left(\mathrm{mAcm}^{-2}\right)$ & $2.80 \times 10^{-5}$ & $2.53 \times 10^{-5}$ & $3.37 \times 10^{-5}$ & $4.04 \times 10^{-5}$ & $6.18 \times 10^{-5}$ & $8.04 \times 10^{-5}$ & $2.17 \times 10^{-5}$ \\
\hline $\mathrm{V}_{\mathrm{mp}} \mathrm{J}_{\mathrm{mp}}\left(\mathrm{VmAcm}{ }^{-2}\right)$ & $4.12 \times 10^{-5}$ & $3.06 \times 10^{-5}$ & $4.89 \times 10^{-5}$ & $9.98 \times 10^{-5}$ & $1.60 \times 10^{-4}$ & $1.95 \times 10^{-4}$ & $4.62 \times 10^{-5}$ \\
\hline $\mathrm{FF}$ & 0.23 & 0.20 & 0.23 & 0.43 & 0.39 & 0.47 & 0.54 \\
\hline $\mathrm{P}_{\text {in }}\left(\mathrm{Wcm}{ }^{-2}\right)$ & $2.32 \times 10^{-4}$ & $2.30 \times 10^{-4}$ & $4.51 \times 10^{-4}$ & $6.75 \times 10^{-4}$ & $9.60 \times 10^{-4}$ & $8.10 \times 10^{-4}$ & $2.48 \times 10^{-4}$ \\
\hline$\eta(\%)$ & 0.17 & 0.13 & 0.11 & 0.15 & 0.34 & 0.39 \\
\hline
\end{tabular}


Table 5: J-V Data for the DSSC Module Studied in Vihiga, with 1 of its Cells Shaded. The Shaded Column has Data Obtained within 0600-0630 Hours Before the Shading. The Irradiance during the Period was $2.50 \times 10^{-04} \mathrm{Wcm}^{-2}$

\begin{tabular}{|c|c|c|c|c|c|c|c|}
\hline Time (Hours) & $0600-0630$ & $0600-0630$ & $0800-0830$ & $1000-1030$ & $1200-1230$ & $1500-1530$ & $1800-1830$ \\
\hline $\mathrm{V}_{\mathrm{oc}}(\mathrm{V})$ & 6.31 & 6.19 & 6.33 & 6.55 & 6.83 & 6.37 & 6.24 \\
\hline $\mathrm{J}_{\mathrm{sc}}\left(\mathrm{mAcm}{ }^{-2}\right)$ & $1.97 \times 10^{-4}$ & $1.49 \times 10^{-4}$ & $2.69 \times 10^{-4}$ & $2.78 \times 10^{-4}$ & $3.92 \times 10^{-4}$ & $2.70 \times 10^{-4}$ & $2.13 \times 10^{-4}$ \\
\hline $\mathrm{V}_{\mathrm{oc}} \mathrm{J}_{\mathrm{sc}}\left(\mathrm{VmAcm}^{-2}\right)$ & $1.24 \times 10^{-3}$ & $9.22 \times 10^{-4}$ & $1.70 \times 10^{-3}$ & $1.82 \times 10^{-3}$ & $2.68 \times 10^{-3}$ & $1.72 \times 10^{-3}$ & $1.33 \times 10^{-3}$ \\
\hline $\mathrm{V}_{\mathrm{mp}}(\mathrm{V})$ & 5.59 & 5.74 & 6.41 & 6.46 & 6.53 & 6.47 & 6.17 \\
\hline FF & 0.75 & 0.73 & 0.69 & 0.62 & 0.50 & 0.66 & 0.56 \\
\hline$P_{\text {in }}\left(\mathrm{Wcm}^{-2}\right)$ & $2.50 \times 10^{-4}$ & $2.39 \times 10^{-4}$ & $4.48 \times 10^{-4}$ & $6.77 \times 10^{-4}$ & $9.88 \times 10^{-4}$ & $8.40 \times 10^{-4}$ & $2.39 \times 10^{-4}$ \\
\hline$\eta(\%)$ & 3.72 & 2.82 & 2.61 & 1.82 & 1.36 & 1.35 & 3.09 \\
\hline
\end{tabular}

Table 6: J-V Data for the DSSC Module Studied in Vihiga, with 2 of its Cells Shaded. The Shaded Column has Data Obtained within 0600-0630 Hours Before the Shading. The Irradiance during the Period was $2.45 \times 10^{-04} \mathrm{Wcm}^{-2}$

\begin{tabular}{|c|c|c|c|c|c|c|c|}
\hline Time (Hours) & $0600-0630$ & $0600-0630$ & $0800-0830$ & $1000-1030$ & $1200-1230$ & $1500-1530$ & $1800-1830$ \\
\hline $\mathrm{V}_{\mathrm{oc}}(\mathrm{V})$ & 5.40 & 5.21 & 5.37 & 5.67 & 6.02 & 5.35 & 5.17 \\
\hline $\mathrm{J}_{\mathrm{sc}}\left(\mathrm{mAcm}^{-2}\right)$ & $1.69 \times 10^{-4}$ & $1.06 \times 10^{-4}$ & $1.87 \times 10^{-4}$ & $2.15 \times 10^{-4}$ & $2.58 \times 10^{-4}$ & $1.89 \times 10^{-4}$ & $1.10 \times 10^{-4}$ \\
\hline $\mathrm{V}_{\mathrm{oc}} \mathrm{J}_{\mathrm{sc}}\left(\mathrm{VmAcm}^{-2}\right)$ & $9.13 \times 10^{-4}$ & $5.52 \times 10^{-4}$ & $1.00 \times 10^{-3}$ & $1.22 \times 10^{-3}$ & $1.56 \times 10^{-3}$ & $1.01 \times 10^{-3}$ & $5.69 \times 10^{-4}$ \\
\hline $\mathrm{V}_{\mathrm{mp}}(\mathrm{V})$ & 4.80 & 4.10 & 4.58 & 4.69 & 4.96 & 4.61 & 4.13 \\
\hline$V_{m p} J_{m p}\left(V_{m A c m}^{-2}\right)$ & $6.38 \times 10^{-4}$ & $3.46 \times 10^{-4}$ & $4.48 \times 10^{-4}$ & $4.61 \times 10^{-4}$ & $4.93 \times 10^{-4}$ & $4.52 \times 10^{-4}$ & $3.52 \times 10^{-4}$ \\
\hline FF & 0.70 & 0.63 & 0.45 & 0.38 & 0.31 & 0.45 & 0.62 \\
\hline$P_{\text {in }}\left(\mathrm{Wcm}^{-2}\right)$ & $2.45 \times 10^{-4}$ & $2.45 \times 10^{-4}$ & $3.48 \times 10^{-4}$ & $6.77 \times 10^{-4}$ & $9.88 \times 10^{-4}$ & $8.40 \times 10^{-4}$ & $2.50 \times 10^{-4}$ \\
\hline$\eta(\%)$ & 2.61 & 1.42 & 1.29 & 0.68 & 0.49 & 0.54 & 1.41 \\
\hline
\end{tabular}

Table 7: J-V Data for the DSSC Module Studied in Vihiga, with 3 of its Cells Shaded. The Shaded Column has Data Obtained within 0600-0630 Hours Before the Shading. The Irradiance during the Period was $2.38 \times 10^{-04} \mathrm{Wcm}^{-2}$

\begin{tabular}{|c|c|c|c|c|c|c|c|}
\hline Time (Hours) & $0600-0630$ & $0600-0630$ & $0800-0830$ & $1000-1030$ & $1200-1230$ & $1500-1530$ & $1800-1830$ \\
\hline$V_{o c}(V)$ & 4.50 & 4.10 & 4.24 & 4.49 & 4.83 & 4.28 & 4.15 \\
\hline $\mathrm{V}_{\mathrm{oc}} \mathrm{J}_{\mathrm{sc}}\left(\mathrm{VmAcm}^{-2}\right)$ & $6.35 \times 10^{-4}$ & $3.87 \times 10^{-4}$ & $4.71 \times 10^{-4}$ & $4.97 \times 10^{-4}$ & $5.94 \times 10^{-4}$ & $4.37 \times 10^{-4}$ & $3.80 \times 10^{-4}$ \\
\hline $\mathrm{V}_{\mathrm{mp}}(\mathrm{V})$ & 3.87 & 3.18 & 3.29 & 3.43 & 3.87 & 3.30 & 3.23 \\
\hline $\mathrm{V}_{\mathrm{mp}} \mathrm{J}_{\mathrm{mp}}\left(\mathrm{VmAcm}^{-2}\right)$ & $4.30 \times 10^{-4}$ & $2.18 \times 10^{-4}$ & $2.31 \times 10^{-4}$ & $2.42 \times 10^{-4}$ & $2.76 \times 10^{-4}$ & $2.32 \times 10^{-4}$ & $2.23 \times 10^{-4}$ \\
\hline $\mathrm{FF}$ & 0.68 & 0.56 & 0.49 & 0.49 & 0.46 & 0.53 & 0.59 \\
\hline$P_{\text {in }}\left(\mathrm{Wcm}^{-2}\right)$ & $2.38 \times 10^{-4}$ & $2.45 \times 10^{-4}$ & $3.48 \times 10^{-4}$ & $6.77 \times 10^{-4}$ & $9.88 \times 10^{-4}$ & $8.40 \times 10^{-4}$ & $2.50 \times 10^{-4}$ \\
\hline$\eta(\%)$ & 1.81 & 0.88 & 0.66 & 0.36 & 0.28 & 0.28 & 0.90 \\
\hline
\end{tabular}


Table 8: J-V Data for the DSSC Module Studied in Vihiga, with 4 of its Cells Shaded. The Shaded Column has Data Obtained within 0600-0630 Hours Before the Shading. The Irradiance during the Period was $2.48 \times 10^{-04} \mathrm{Wcm}^{-2}$

\begin{tabular}{|c|c|c|c|c|c|c|c|}
\hline Time (Hours) & $0600-0630$ & $0600-0630$ & $0800-0830$ & $1000-1030$ & $1200-1230$ & $1500-1530$ & $1800-1830$ \\
\hline $\mathrm{V}_{\mathrm{oc}}(\mathrm{V})$ & 3.60 & 2.73 & 2.85 & 3.08 & 3.45 & 3.13 & 2.77 \\
\hline $\mathrm{J}_{\mathrm{sc}}\left(\mathrm{mAcm}{ }^{-2}\right)$ & $9.90 \times 10^{-5}$ & $6.31 \times 10^{-5}$ & $6.46 \times 10^{-5}$ & $7.50 \times 10^{-5}$ & $8.79 \times 10^{-5}$ & $8.17 \times 10^{-5}$ & $6.40 \times 10^{-5}$ \\
\hline $\mathrm{V}_{\mathrm{oc}} \mathrm{J}_{\mathrm{sc}}\left(\mathrm{VmAcm}^{-2}\right)$ & $3.56 \times 10^{-4}$ & $1.72 \times 10^{-4}$ & $3.92 \times 10^{-4}$ & $2.31 \times 10^{-4}$ & $3.03 \times 10^{-4}$ & $2.56 \times 10^{-4}$ & $1.78 \times 10^{-4}$ \\
\hline $\mathrm{V}_{\mathrm{mp}}(\mathrm{V})$ & 2.58 & 2.06 & 2.19 & 2.24 & 2.52 & 2.31 & 2.10 \\
\hline FF & 0.53 & 0.51 & 0.26 & 0.45 & 0.42 & 0.45 & 0.51 \\
\hline $\mathrm{P}_{\text {in }}\left(\mathrm{Wcm}^{-2}\right)$ & $2.48 \times 10^{-4}$ & $2.45 \times 10^{-4}$ & $3.48 \times 10^{-4}$ & $6.77 \times 10^{-4}$ & $9.88 \times 10^{-4}$ & $8.40 \times 10^{-4}$ & $2.50 \times 10^{-4}$ \\
\hline$\eta(\%)$ & 0.76 & 0.36 & 0.29 & 0.15 & 0.13 & 0.14 & 0.36 \\
\hline
\end{tabular}

Table 9: J-V Data for the DSSC Module Studied in Vihiga, with 5 of its Cells Shaded. The Shaded Column has Data Obtained within 0600-0630 Hours Before the Shading. The Irradiance during the Period was $2.45 \times 10^{-04} \mathrm{Wcm}^{-2}$

\begin{tabular}{|c|c|c|c|c|c|c|c|}
\hline Time (Hours) & $0600-0630$ & $0600-0630$ & $0800-0830$ & $1000-1030$ & $1200-1230$ & $1500-1530$ & $1800-1830$ \\
\hline $\mathrm{V}_{\mathrm{oc}}(\mathrm{V})$ & 2.07 & 1.37 & 1.47 & 1.54 & 1.63 & 1.39 & 1.28 \\
\hline $\mathrm{V}_{\mathrm{oc}} \mathrm{J}_{\mathrm{sc}}\left(\mathrm{VmAcm}^{-2}\right)$ & $1.11 \times 10^{-4}$ & $4.33 \times 10^{-5}$ & $4.82 \times 10^{-5}$ & $5.61 \times 10^{-5}$ & $6.67 \times 10^{-5}$ & $3.73 \times 10^{-5}$ & $2.16 \times 10^{-5}$ \\
\hline $\mathrm{V}_{\mathrm{mp}}(\mathrm{V})$ & 1.29 & 1.03 & 1.06 & 1.08 & 1.12 & 1.03 & 1.00 \\
\hline $\mathrm{V}_{\mathrm{mp}} \mathrm{J}_{\mathrm{mp}}\left(\mathrm{VmAcm}^{-2}\right)$ & $4.77 \times 10^{-5}$ & $1.68 \times 10^{-5}$ & $1.79 \times 10^{-5}$ & $1.85 \times 10^{-5}$ & $2.09 \times 10^{-5}$ & $1.59 \times 10^{-5}$ & $1.02 \times 10^{-5}$ \\
\hline $\mathrm{FF}$ & 0.63 & 0.39 & 0.37 & 0.32 & 0.31 & 0.43 & 0.47 \\
\hline$P_{\text {in }}\left(\mathrm{Wcm}^{-2}\right)$ & $2.45 \times 10^{-4}$ & $2.45 \times 10^{-4}$ & $3.48 \times 10^{-4}$ & $6.77 \times 10^{-4}$ & $9.88 \times 10^{-4}$ & $8.40 \times 10^{-4}$ & $2.50 \times 10^{-4}$ \\
\hline$\eta(\%)$ & 0.19 & 0.07 & 0.05 & 0.03 & 0.02 & 0.02 & 0.04 \\
\hline
\end{tabular}

Table 10: J-V Data for the DSSC Module Studied in Kitui, with 1 of its Cells Shaded. The Shaded Column has Data Obtained within 0600-0630 Hours Before the Shading. The Irradiance during the Period was $2.45 \times 10^{-04} \mathrm{Wcm}^{-2}$

\begin{tabular}{|c|c|c|c|c|c|c|c|}
\hline Time (Hours) & $0600-0630$ & $0600-0630$ & $0800-0830$ & $1000-1030$ & $1200-1230$ & $1500-1530$ & $1800-1830$ \\
\hline$V_{o c}(V)$ & 7.07 & 6.89 & 6.97 & 7.11 & 7.23 & 7.08 & 6.75 \\
\hline $\mathrm{V}_{\mathrm{oc}} \mathrm{J}_{\mathrm{sc}}\left(\mathrm{VmAcm}^{-2}\right)$ & $2.11 \times 10^{-3}$ & $1.94 \times 10^{-3}$ & $2.20 \times 10^{-3}$ & $3.11 \times 10^{-3}$ & $3.78 \times 10^{-3}$ & $3.02 \times 10^{-3}$ & $1.87 \times 10^{-3}$ \\
\hline $\mathrm{V}_{\mathrm{mp}}(\mathrm{V})$ & 6.61 & 6.37 & 6.44 & 6.71 & 6.91 & 6.49 & 6.32 \\
\hline$V_{m p} J_{m p}\left(V_{m A c m}^{-2}\right)$ & $1.30 \times 10^{-3}$ & $1.13 \times 10^{-3}$ & $1.17 \times 10^{-3}$ & $1.56 \times 10^{-3}$ & $1.83 \times 10^{-3}$ & $1.76 \times 10^{-3}$ & $1.19 \times 10^{-3}$ \\
\hline $\mathrm{FF}$ & 0.62 & 0.58 & 0.53 & 0.50 & 0.48 & 0.58 & 0.63 \\
\hline$P_{\text {in }}\left(\mathrm{Wcm}^{-2}\right)$ & $2.45 \times 10^{-4}$ & $2.45 \times 10^{-4}$ & $4.73 \times 10^{-4}$ & $7.10 \times 10^{-4}$ & $9.28 \times 10^{-4}$ & $7.81 \times 10^{-4}$ & $3.21 \times 10^{-4}$ \\
\hline$\eta(\%)$ & 5.54 & 4.59 & 2.47 & 2.19 & 1.96 & 2.24 & 3.67 \\
\hline
\end{tabular}


Table 11: J-V Data for the DSSC Module Studied in Kitui, with 2 of its Cells Shaded. The Shaded Column has Data Obtained within 0600-0630 Hours Before the Shading. The Irradiance during the Period was $2.41 \times 10^{-04} \mathrm{Wcm}^{-2}$

\begin{tabular}{|c|c|c|c|c|c|c|c|}
\hline Time (Hours) & $0600-0630$ & $0600-0630$ & $0800-0830$ & $1000-1030$ & $1200-1230$ & $1500-1530$ & $1800-1830$ \\
\hline $\mathrm{V}_{\mathrm{oc}}(\mathrm{V})$ & 6.08 & 5.90 & 5.97 & 6.09 & 6.20 & 6.07 & 5.79 \\
\hline $\mathrm{J}_{\mathrm{sc}}\left(\mathrm{mAcm}{ }^{-2}\right)$ & $2.55 \times 10^{-4}$ & $1.61 \times 10^{-4}$ & $1.81 \times 10^{-4}$ & $2.50 \times 10^{-4}$ & $2.98 \times 10^{-4}$ & $2.44 \times 10^{-4}$ & $1.58 \times 10^{-4}$ \\
\hline $\mathrm{V}_{\mathrm{oc}} \mathrm{J}_{\mathrm{sc}}\left(\mathrm{VmAcm}^{-2}\right)$ & $1.55 \times 10^{-3}$ & $9.50 \times 10^{-4}$ & $1.08 \times 10^{-3}$ & $1.52 \times 10^{-3}$ & $1.85 \times 10^{-3}$ & $1.48 \times 10^{-3}$ & $9.15 \times 10^{-4}$ \\
\hline $\mathrm{V}_{\mathrm{mp}}(\mathrm{V})$ & 5.47 & 4.55 & 4.60 & 4.79 & 4.90 & 4.64 & 4.51 \\
\hline $\mathrm{FF}$ & 0.56 & 0.48 & 0.44 & 0.42 & 0.39 & 0.49 & 0.53 \\
\hline$P_{\text {in }}\left(W_{c m}^{-2}\right)$ & $2.41 \times 10^{-4}$ & $2.45 \times 10^{-4}$ & $4.73 \times 10^{-4}$ & $7.10 \times 10^{-4}$ & $9.28 \times 10^{-4}$ & $7.81 \times 10^{-4}$ & $3.21 \times 10^{-4}$ \\
\hline$\eta(\%)$ & 3.60 & 1.86 & 1.00 & 0.90 & 0.78 & 0.93 & 1.51 \\
\hline
\end{tabular}

Table 12: J-V Data for the DSSC Module Studied in Kitui, with 3 of its Cells Shaded. The Shaded Column has Data Obtained within 0600-0630 Hours Before the Shading. The Irradiance during the Period was $2.45 \times 10^{-04} \mathrm{Wcm}^{-2}$

\begin{tabular}{|c|c|c|c|c|c|c|c|}
\hline Time (Hours) & $0600-0630$ & $0600-0630$ & $0800-0830$ & $1000-1030$ & $1200-1230$ & $1500-1530$ & $1800-1830$ \\
\hline $\mathrm{V}_{\mathrm{oc}}(\mathrm{V})$ & 5.21 & 5.06 & 5.12 & 5.22 & 5.31 & 5.20 & 4.96 \\
\hline $\mathrm{J}_{\mathrm{sc}}\left(\mathrm{mAcm}^{-2}\right)$ & $1.46 \times 10^{-4}$ & $9.20 \times 10^{-4}$ & $1.03 \times 10^{-4}$ & $1.43 \times 10^{-4}$ & $1.70 \times 10^{-4}$ & $1.39 \times 10^{-4}$ & $9.03 \times 10^{-5}$ \\
\hline $\mathrm{V}_{\mathrm{oc}} \mathrm{J}_{\mathrm{sc}}\left(\mathrm{VmAcm}^{-2}\right)$ & $7.61 \times 10^{-4}$ & $4.66 \times 10^{-4}$ & $5.27 \times 10^{-4}$ & $7.46 \times 10^{-4}$ & $9.02 \times 10^{-4}$ & $7.23 \times 10^{-4}$ & $4.48 \times 10^{-4}$ \\
\hline $\mathrm{V}_{\mathrm{mp}}(\mathrm{V})$ & 4.19 & 3.87 & 3.94 & 4.11 & 4.20 & 3.98 & 3.87 \\
\hline$V_{m p} J_{m p}\left(V m A c m^{-2}\right)$ & $3.78 \times 10^{-4}$ & $2.23 \times 10^{-4}$ & $2.34 \times 10^{-4}$ & $3.12 \times 10^{-4}$ & $3.53 \times 10^{-4}$ & $3.98 \times 10^{-4}$ & $2.36 \times 10^{-4}$ \\
\hline $\mathrm{FF}$ & 0.50 & 0.48 & 0.44 & 0.42 & 0.39 & 0.55 & 0.53 \\
\hline$P_{\text {in }}\left(\mathrm{Wcm}^{-2}\right)$ & $2.45 \times 10^{-4}$ & $2.45 \times 10^{-4}$ & $4.73 \times 10^{-4}$ & $7.10 \times 10^{-4}$ & $9.28 \times 10^{-4}$ & $7.81 \times 10^{-4}$ & $3.12 \times 10^{-4}$ \\
\hline$\eta(\%)$ & 1.55 & 0.91 & 0.49 & 0.44 & 0.38 & 0.51 & 0.74 \\
\hline
\end{tabular}

Table 13: J-V Data for the DSSC Module Studied in Kitui, with 4 of its Cells Shaded. The Shaded Column has Data Obtained within 0600-0630 Hours Before the Shading. The Irradiance during the Period was $2.47 \times 10^{-04} \mathrm{Wcm}^{-2}$

\begin{tabular}{|c|c|c|c|c|c|c|c|}
\hline Time (Hours) & $\mathbf{0 6 0 0 - 0 6 3 0}$ & $\mathbf{0 6 0 0 - 0 6 3 0}$ & $\mathbf{0 8 0 0 - 0 8 3 0}$ & $\mathbf{1 0 0 0 - 1 0 3 0}$ & $\mathbf{1 2 0 0 - 1 2 3 0}$ & $\mathbf{1 5 0 0 - 1 5 3 0}$ & $\mathbf{1 8 0 0 - 1 8 3 0}$ \\
\hline \hline $\mathrm{V}_{\mathrm{oc}}(\mathrm{V})$ & 4.47 & 3.61 & 3.66 & 3.72 & 3.79 & 3.71 \\
\hline $\mathrm{J}_{\mathrm{sc}}\left(\mathrm{mAcm}^{-2}\right)$ & $8.34 \times 10^{-5}$ & $5.26 \times 10^{-5}$ & $5.89 \times 10^{-5}$ & $8.17 \times 10^{-5}$ & $9.71 \times 10^{-5}$ & $7.94 \times 10^{-5}$ & $5.16 \times 10^{-5}$ \\
\hline $\mathrm{V}_{\text {oc }} \mathrm{J}_{\mathrm{sc}}\left(\mathrm{VmAcm}^{-2}\right)$ & $3.73 \times 10^{-4}$ & $1.90 \times 10^{-4}$ & $2.16 \times 10^{-4}$ & $3.04 \times 10^{-4}$ & $3.68 \times 10^{-4}$ & $2.95 \times 10^{-4}$ & $1.83 \times 10^{-4}$ \\
\hline $\mathrm{V}_{\mathrm{mp}}(\mathrm{V})$ & 2.99 & 2.36 & 2.51 & 2.54 & 2.73 & 2.64 & 2.34 \\
\hline $\mathrm{J}_{\mathrm{mp}}\left(\mathrm{mAcm}^{-2}\right)$ & $5.15 \times 10^{-5}$ & $3.07 \times 10^{-5}$ & $3.19 \times 10^{-5}$ & $4.04 \times 10^{-5}$ & $4.19 \times 10^{-5}$ & $4.06 \times 10^{-5}$ & $3.30 \times 10^{-5}$ \\
\hline $\mathrm{V}_{\mathrm{mp}} \mathrm{J}_{\mathrm{mp}}\left(\mathrm{VmAcm}{ }^{-2}\right)$ & $1.54 \times 10^{-4}$ & $7.24 \times 10^{-5}$ & $8.01 \times 10^{-5}$ & $1.03 \times 10^{-4}$ & $1.14 \times 10^{-4}$ & $1.07 \times 10^{-4}$ & $7.72 \times 10^{-5}$ \\
\hline $\mathrm{FF}$ & 0.41 & 0.38 & 0.37 & 0.34 & 0.31 & 0.36 & 0.42 \\
\hline$P_{\text {in }}\left(\mathrm{Wcm}{ }^{-2}\right)$ & $2.47 \times 10^{-4}$ & $2.45 \times 10^{-4}$ & $4.73 \times 10^{-4}$ & $7.10 \times 10^{-4}$ & $9.28 \times 10^{-4}$ & $7.81 \times 10^{-4}$ & $3.12 \times 10^{-4}$ \\
\hline$\eta(\%)$ & 0.62 & 0.29 & 0.17 & 0.15 & 0.12 & 0.14 & 0.24 \\
\hline
\end{tabular}

were: $\mathrm{V}_{\mathrm{oc}}=1.48 \mathrm{~V}, \mathrm{~J}_{\mathrm{sc}}=3.07 \times 10^{-5} \mathrm{mAcm}^{-2}, \mathrm{FF}=0.36$ and $\eta=0.07$, which demonstrate some degrees of recovery after the various $\mathrm{RB}$ regimes.

\subsection{DSSC Module Performances in Kitui}

Subjecting the module to RB potential of $2 \mathrm{~V}, 3 \mathrm{~V}$ and $4 \mathrm{~V}$ resulted in $48.33 \%, 41.29 \%$ and $53.23 \%$ drop in 
Table 14: J-V Data for the DSSC Module Studied in Kajiado, with 1 of its Cells Shaded. The Shaded Column has Data Obtained within 0600-0630 Hours Before Shading. The Irradiance during the Period was $1.89 \times 10^{-04} \mathrm{Wcm}^{-2}$

\begin{tabular}{|c|c|c|c|c|c|c|c|}
\hline Time (Hours) & $0600-0630$ & $0600-0630$ & $0800-0830$ & $1000-1030$ & $1200-1230$ & $1500-1530$ & $1800-1830$ \\
\hline$V_{o c}(V)$ & 6.92 & 6.24 & 6.37 & 6.96 & 7.03 & 6.91 & 6.32 \\
\hline $\mathrm{J}_{\mathrm{sc}}\left(\mathrm{mAcm}{ }^{-2}\right)$ & $1.95 \times 10^{-4}$ & $1.38 \times 10^{-4}$ & $2.19 \times 10^{-4}$ & $3.64 \times 10^{-4}$ & $4.71 \times 10^{-4}$ & $3.59 \times 10^{-4}$ & $1.61 \times 10^{-4}$ \\
\hline $\mathrm{V}_{\mathrm{oc}} \mathrm{J}_{\mathrm{sc}}\left(\mathrm{VmAcm}^{-2}\right)$ & $1.35 \times 10^{-3}$ & $8.61 \times 10^{-4}$ & $1.40 \times 10^{-3}$ & $2.53 \times 10^{-3}$ & $3.31 \times 10^{-3}$ & $2.48 \times 10^{-3}$ & $1.02 \times 10^{-3}$ \\
\hline $\mathrm{V}_{\mathrm{mp}}(\mathrm{V})$ & 5.89 & 4.92 & 5.02 & 5.16 & 5.31 & 5.22 & 4.97 \\
\hline $\mathrm{FF}$ & 0.58 & 0.57 & 0.43 & 0.32 & 0.27 & 0.32 & 0.51 \\
\hline$P_{\text {in }}\left(\mathrm{Wcm}^{-2}\right)$ & $1.89 \times 10^{-4}$ & $1.89 \times 10^{-4}$ & $4.01 \times 10^{-4}$ & $5.83 \times 10^{-4}$ & $7.54 \times 10^{-4}$ & $6.19 \times 10^{-4}$ & $3.11 \times 10^{-4}$ \\
\hline$\eta(\%)$ & 4.14 & 2.60 & 1.50 & 1.39 & 1.19 & 1.28 & 1.67 \\
\hline
\end{tabular}

Table 15: J-V Data for the DSSC Module Studied in Kajiado, with 2 of its Cells Shaded. The Shaded Column has Data Obtained within 0600-0630 Hours Before Shading. The Irradiance during the Period was $1.91 \times 10^{-04} \mathrm{Wcm}^{-2}$

\begin{tabular}{|c|c|c|c|c|c|c|c|}
\hline Time (Hours) & $0600-0630$ & $0600-0630$ & $0800-0830$ & $1000-1030$ & $1200-1230$ & $1500-1530$ & $1800-1830$ \\
\hline$V_{o c}(V)$ & 5.93 & 5.46 & 5.72 & 5.97 & 6.03 & 5.92 & 5.42 \\
\hline $\mathrm{V}_{\mathrm{oc}} \mathrm{J}_{\mathrm{sc}}\left(\mathrm{VmAcm}^{-2}\right)$ & $6.58 \times 10^{-4}$ & $4.64 \times 10^{-4}$ & $7.15 \times 10^{-4}$ & $1.24 \times 10^{-3}$ & $1.62 \times 10^{-3}$ & $1.21 \times 10^{-3}$ & $4.99 \times 10^{-4}$ \\
\hline $\mathrm{V}_{\mathrm{mp}}(\mathrm{V})$ & 4.21 & 4.22 & 4.30 & 4.42 & 4.55 & 4.47 & 4.26 \\
\hline $\mathrm{V}_{\mathrm{mp}} \mathrm{J}_{\mathrm{mp}}\left(\mathrm{VmAcm}^{-2}\right)$ & $3.17 \times 10^{-4}$ & $1.99 \times 10^{-4}$ & $2.92 \times 10^{-4}$ & $4.02 \times 10^{-4}$ & $4.45 \times 10^{-4}$ & $3.86 \times 10^{-4}$ & $2.53 \times 10^{-4}$ \\
\hline $\mathrm{FF}$ & 0.48 & 0.43 & 0.41 & 0.32 & 0.27 & 0.32 & 0.50 \\
\hline$P_{\text {in }}\left(\mathrm{Wcm}^{-2}\right)$ & $1.91 \times 10^{-4}$ & $1.90 \times 10^{-4}$ & $4.05 \times 10^{-4}$ & $5.82 \times 10^{-4}$ & $7.54 \times 10^{-4}$ & $6.19 \times 10^{-4}$ & $3.11 \times 10^{-4}$ \\
\hline$\eta(\%)$ & 1.65 & 1.05 & 0.72 & 0.68 & 0.58 & 0.63 & 0.80 \\
\hline
\end{tabular}

Table 16: J-V Data for the DSSC Module Studied in Kajiado, with 3 of its Cells Shaded. The Shaded Column has Data Obtained within 0600-0630 Hours Before Shading. The Irradiance during the Period was $1.89 \times 10^{-04} \mathrm{Wcm}^{-2}$

\begin{tabular}{|c|c|c|c|c|c|c|c|}
\hline Time (Hours) & $\mathbf{0 6 0 0 - 0 6 3 0}$ & $\mathbf{0 6 0 0 - 0 6 3 0}$ & $\mathbf{0 8 0 0 - 0 8 3 0}$ & $\mathbf{1 0 0 0 - 1 0 3 0}$ & $\mathbf{1 2 0 0 - 1 2 3 0}$ & $\mathbf{1 5 0 0 - 1 5 3 0}$ & $\mathbf{1 8 0 0 - 1 8 3 0}$ \\
\hline \hline $\mathrm{V}_{\mathrm{oc}}(\mathrm{V})$ & 4.38 & 3.68 & 3.90 & 4.12 & 4.17 & 4.07 \\
\hline $\mathrm{J}_{\mathrm{sc}}\left(\mathrm{mAcm}{ }^{-2}\right)$ & $9.51 \times 10^{-5}$ & $4.85 \times 10^{-5}$ & $6.00 \times 10^{-5}$ & $1.19 \times 10^{-4}$ & $1.54 \times 10^{-4}$ & $1.17 \times 10^{-4}$ & $5.26 \times 10^{-5}$ \\
\hline $\mathrm{V}_{\mathrm{oc}} \mathrm{J}_{\mathrm{sc}}\left(\mathrm{VmAcm}{ }^{-2}\right)$ & $4.17 \times 10^{-4}$ & $1.78 \times 10^{-4}$ & $2.34 \times 10^{-4}$ & $4.90 \times 10^{-4}$ & $6.42 \times 10^{-4}$ & $4.76 \times 10^{-4}$ & $1.92 \times 10^{-4}$ \\
\hline $\mathrm{V}_{\mathrm{mp}}(\mathrm{V})$ & 3.70 & 2.42 & 2.69 & 2.79 & 2.90 & 2.83 & 2.65 \\
\hline $\mathrm{J}_{\mathrm{mp}}\left(\mathrm{mAcm}{ }^{-2}\right)$ & $6.86 \times 10^{-5}$ & $3.05 \times 10^{-5}$ & $3.89 \times 10^{-5}$ & $5.19 \times 10^{-5}$ & $5.58 \times 10^{-5}$ & $4.93 \times 10^{-5}$ & $3.14 \times 10^{-5}$ \\
\hline $\mathrm{V}_{\mathrm{mp}} \mathrm{J}_{\mathrm{mp}}\left(\mathrm{VmAcm}{ }^{-2}\right)$ & $2.54 \times 10^{-4}$ & $1.04 \times 10^{-4}$ & $1.44 \times 10^{-4}$ & $1.97 \times 10^{-4}$ & $2.18 \times 10^{-4}$ & $1.89 \times 10^{-4}$ & $1.14 \times 10^{-4}$ \\
\hline $\mathrm{FF}$ & 0.61 & 0.58 & 0.62 & 0.40 & 0.34 & 0.40 & 0.45 \\
\hline$P_{\text {in }}\left(\mathrm{Wcm}{ }^{-2}\right)$ & $1.89 \times 10^{-4}$ & $1.89 \times 10^{-4}$ & $4.01 \times 10^{-4}$ & $5.83 \times 10^{-4}$ & $7.54 \times 10^{-4}$ & $6.19 \times 10^{-4}$ & $3.11 \times 10^{-4}$ \\
\hline$\eta(\%)$ & 1.35 & 0.55 & 0.36 & 0.34 & 0.29 & 0.31 & 0.59 \\
\hline
\end{tabular}


Table 17: J-V Data for the DSSC Module Studied in Kajiado, with 4 of its Cells Shaded. The Shaded Column has Data Obtained within 0600-0630 Hours Before Shading. The Irradiance during the Period was $1.90 \times 10^{-04} \mathrm{Wcm}^{-2}$

\begin{tabular}{|c|c|c|c|c|c|c|c|}
\hline Time (Hours) & $0600-0630$ & $0600-0630$ & $0800-0830$ & $1000-1030$ & $1200-1230$ & $1500-1530$ & $1800-1830$ \\
\hline $\mathrm{V}_{\mathrm{oc}}(\mathrm{V})$ & 3.35 & 3.01 & 3.20 & 3.39 & 3.43 & 3.35 & 2.99 \\
\hline $\mathrm{J}_{\mathrm{sc}}\left(\mathrm{mAcm} \mathrm{c}^{-2}\right)$ & $5.43 \times 10^{-5}$ & $2.77 \times 10^{-5}$ & $3.43 \times 10^{-5}$ & $6.80 \times 10^{-5}$ & $8.80 \times 10^{-5}$ & $6.69 \times 10^{-5}$ & $3.01 \times 10^{-5}$ \\
\hline $\mathrm{V}_{\mathrm{oc}} \mathrm{J}_{\mathrm{sc}}\left(\mathrm{VmAcm}^{-2}\right)$ & $1.82 \times 10^{-4}$ & $8.34 \times 10^{-5}$ & $1.10 \times 10^{-4}$ & $2.31 \times 10^{-4}$ & $3.02 \times 10^{-4}$ & $2.24 \times 10^{-4}$ & $9.00 \times 10^{-5}$ \\
\hline $\mathrm{V}_{\mathrm{mp}}(\mathrm{V})$ & 3.09 & 1.93 & 1.16 & 1.25 & 1.34 & 1.28 & 1.13 \\
\hline $\mathrm{FF}$ & 0.46 & 0.40 & 0.23 & 0.16 & 0.14 & 0.16 & 0.22 \\
\hline $\mathrm{P}_{\text {in }}\left(\mathrm{Wcm}^{-2}\right)$ & $1.90 \times 10^{-4}$ & $1.89 \times 10^{-4}$ & $4.01 \times 10^{-4}$ & $5.83 \times 10^{-4}$ & $7.54 \times 10^{-4}$ & $6.19 \times 10^{-4}$ & $3.11 \times 10^{-4}$ \\
\hline$\eta(\%)$ & 0.40 & 0.18 & 0.06 & 0.06 & 0.06 & 0.06 & 0.06 \\
\hline
\end{tabular}

$\eta$, respectively. The module however recovered its $\eta$ performance when these shadings were removed. It was nonetheless irrecoverably degraded when subjected to RB of $5 \mathrm{~V}$.

\subsection{DSSC Module Performances in Kajiado}

The module lost $37.20 \%, 36.36 \%, 59.26 \%$ and $55 \%$ in $\eta$ when $1,2,3$ and 4 of its cells were shaded, respectively. Subjecting it to RB potential of $5 \mathrm{~V}$ led to total degradation of the module. These results demonstrate the module's ability to recover after RBinduced degradation, but only up to some critical limit.

\section{DISCUSSION}

Degradation of the modules' $\eta$ under various RB potentials in Wajir, Vihiga, Kitui and Kajiado could be attributed to the fact that when a cell in series connection in a module is shaded, current passes such cell in reverse direction compared to the norm. In such situations, the shaded cell experiences voltage that is in reverse direction to that from the other cells in the module that are lit. External microclimates are therefore critical in influencing the degree of degradation of a module's $\eta$ when the module is subjected to RB. Table 18 presents a summary of degradation in $\eta$ of the modules that were investigated in Wajir, Vihiga, Kitui and Kajiado, under varying RB regimes.

The module that was investigated in Kajiado had the highest degradation in $\eta$ when one of its cells was subjected to RB of $1 \mathrm{~V}$, i.e., $37.20 \%$, while the module that was investigated in Kitui had the least degradation in $\eta$ when one of its cells was subjected to RB of $1 \mathrm{~V}$, i.e., $15.73 \%$. This finding was evaluated alongside that of $\eta$ loss by the modules when only one of their cells was not shaded, i.e., under RB of $4 \mathrm{~V}$, which were $23.53 \%, 52.63 \%, 53.23 \%$ and $55.00 \%$ for the modules investigated in Wajir, Vihiga, Kitui, and Kajiado, respectively. Under RB of $4 \mathrm{~V}$, the module investigated in Wajir had the least loss in $\eta$, i.e., $23.53 \%$, while the highest loss in $\eta$ was by the module that was investigated in Kajiado, i.e., $55.00 \%$.

These results demonstrate that microclimatic conditions where a DSSC module operates influence its rate of $\eta$ degradation when operating under RB. The module's ability to partly recover in $\eta$ after degradation appears to have been influenced by the prevailing microclimatic conditions. Particularly, the microclimatic environments characterised by high ambient temperatures posted less degradation in $\eta$ for the modules operating there, compared to environments

Table 18: The DSSC Modules' $\eta$ under Varied RB Regimes in Wajir, Vihiga, Kitui and Kajiado

\begin{tabular}{|c|c|c|c|c|c|}
\hline & 1V Reverse Bias & 2V Reverse Bias & 3V Reverse Bias & 4V Reverse Bias & 5V Reverse Bias \\
\hline \hline Wajir & $25.53 \%$ & $36.19 \%$ & $27.52 \%$ & $23.53 \%$ & - \\
\hline Vihiga & $24.19 \%$ & $45.59 \%$ & $51.38 \%$ & $52.63 \%$ & $63.16 \%$ \\
\hline Kitui & $15.73 \%$ & $48.33 \%$ & $41.29 \%$ & $53.23 \%$ & - \\
\hline Kajiado & $37.20 \%$ & $36.36 \%$ & $59.26 \%$ & $55.00 \%$ & - \\
\hline
\end{tabular}


with low ambient temperatures. This could be attributed to the fact that increased temperatures make the electron quasi-fermi levels in the modules to shift towards the conduction band edge of the $\mathrm{TiO}_{2}$ semiconductor in the DSSCs, thus improving their performance. Similar observations have been reported in respect of other DSSC performance studies [26-29]. Roux has linked the temperature-dependence of degradation in $\eta$ to changes in ligands within the modules, and opining that temperatures benefit DSSC dye operation, which profits DSSC module performances [28].

\section{CONCLUSION AND RECOMMENDATIONS}

DSSCs present a viable prospect for increasing access to clean energy services, especially for people in areas hitherto deprived of these services in Kenya. This is because they can be self-assembled, use locally available resources, do not require the overly stringent fabrication environments that are associated with other categories of solar cells, and do not also require very high photon energy thresholds to commence electricity generation. These benefits enhance DSSCs' affordability, and provide opportunity for their application in PV-integrated designs in textile fabrics and architecture for use particularly in areas currently deprived of clean energy services. DSSCs that are integrated in textile fabrics and architecture would be prone to effects of RB. In practical situations, textile fabrics and buildings encounter shading, either due to their use, positioning, or location; factors that ought to be considered in PV-integrated designs. This study has established that prevailing microclimatic conditions influence the rate of degradation of DSSCs operating under RB.

It is therefore recommended that designs on DSSC application, including energy-conscious design practices for PV-integrated textile fabrics and architecture, be guided by context-informed shading realities. For example, among most pastoralist communities in Kenya, use of cultural shuka is common. The shuka is often wrapped around the body and, is a good opportunity for integrated photovoltaics for clean energy services, like telephone charging and lighting. Understanding how communities make use of their cultural fabrics would assist to appreciate how shading may manifest on the fabrics; hence could help in innovating informed PV-integrated cultural fabric designs. These also applies to other PV-integrated designs, like building façades. This approach to PVintegrated designs holds prospects for location-distinct
PV-integrated designs that are underpinned by existing cultural values, as well as microclimatic environments. The approach could also help in stimulating innovation in PV-integrated designs at local levels, hence, decentralization of allied job prospects.

\section{REFERENCES}

[1] Allen M, Frame D, Huntingford C, Jones C, Lowe J, Meinshausen $\mathrm{N}$. Warning caused by cumulative carbon emissions towards the trillion tone. Nature 2009; 458: 1163-1166. https://doi.org/10.1038/nature08019

[2] Otakwa R, Othieno H, Awange J, Oduor A. Technology options for the built environment in Kenya: Dye-sensitized and amorphous silicon photovoltaics for application in NZE buildings. Current Alternative Energy 2017; 1: 1-10. https://doi.org/10.2174/2405463102666170306162043

[3] Perry S, Klemes J, Bulatov I. Integrated waste and renewable energy to reduce the carbon footprint of locally integrated energy sectors. Energy 2008; 33: 1489-1497. https://doi.org/10.1016/j.energy.2008.03.008

[4] Mui S, Law K, Chan M. Carbon reduction opportunities in the California Petroleum Industry. NRDC Issue Brief, 2013; IB: 13-09-E, 1-15.

[5] Meggers F, Leibundgut $\mathrm{H}$, Kennedy S, Qin M, Schlaich M Sobek W, Shukuya M. Reduce CO2 from buildings with technology to zero emissions. Sustainable Cities and Society 2012; 2: 29-36. https://doi.org/10.1016/j.scs.2011.10.001

[6] Mather R, Wilson J. Fabrication of photovoltaic textiles. Coatings 2017; 7(63): 1-21. https://doi.org/10.3390/coatings 7050063

[7] Zeng W, Shu L, Li Q, Chen S, Wang F, Tao X. Fibre-based wearable electronics: A review of materials, fabrication, devices, and applications. Advanced Materials 2014; 26: 5310-5336.

https://doi.org/10.1002/adma.201400633

[8] Ostfeld A, Arias A. Flexible photovoltaic power systems: integration opportunities, challenges and advances. Flexible and Printed Electronics 2017; 2: 013001. https://doi.org/10.1088/2058-8585/aa5750

[9] Nussbaumer P, Bazilian M, Modi V, Yumkella K. Measuring energy poverty: Focusing on what matters. Oxford: Oxford Poverty and Human Development Initiative (OPHI) 2011.

[10] Rim S, Baldrias M, Morse M. Temperature of solar cells in reverse bias: Theory and application. 2010 35th IEEE Photovoltaic Specialists Conference. Honolulu, HI: 2010; pp. 002698-002700. https://doi.org/10.1109/PVSC.2010.5616916

[11] Kurtz S, Wohlgemuth J, Kempe M, Bosco N, Hacke $P$, Jordan D, Miller D, Silverman T, Phillips $N$, Earnest $T$, Romero R. Photovoltaic module qualification plus testing. Denver West Parkway: National Renewable Energy Laboratory (NREL) 2013.

[12] Vasko A, Vijh A, Karpov V. Hot spots spontaneously emerging in thin film photovoltaics 2013. arXiv: https://arxiv.org/pdf/1401.0056.pdf , 1-10.

[13] Rajagopal A, Williams S, Chueh C, Jen A. Abnormal currentvoltage hysteresis induced by reverse bias in organicinorganic hybrid perovskite photovoltaics. The Journal of Physical Chemistry Letters 2016; 7(6): 995-1003. https://doi.org/10.1021/acs.jpclett.6b00058

[14] Kern R, Sastrawan R, Ferber J, Stangl R, Luther J. Modelling and interpretation of electrical impedance spectra of dye solar cells operated under open circuit conditions. Electrochimica Acta 2002; 47: 4213-4225. https://doi.org/10.1016/S0013-4686(02)00444-9 
[15] Roux L, Knoesen D, Hietkamp S. Spectroscopic and impedance studies of reverse biased degraded dye solar cells. Pretoria: CSIR Materials Science and Manufacturing, Energy and Processes 2011.

[16] Hinsch A, Belledin U, Brandt $H$, Einsele F, Hemming S, Koch D, Ran U, Sastrawan R, Schauer T. Glass frit sealed dye solar modules with adaptable screen printed design. 4th World Conference on Photovoltaic Energy Conversion. Hawaii 2006.

[17] Milkevitch M, Brauns E, Brewer K. Spectroscopic and electrochemical properties of a series of mixed-metal $d^{\wedge} 6$, $\mathrm{d}^{\wedge} 8$ Bimetallic Complexes of the form [(Bpy)2m(BL)PtCls $)^{\wedge} 2+$ Quinoxalle) or $\mathrm{dpb}(2,3-B i s(2-$ Pyridyl)-Benzoquinoxaline); $\mathrm{M}=\mathrm{Os}$ " or Ru"). Inorganic Chemistry, 1996; 35(6): 17371739. https://doi.org/10.1021/ic950693y

[18] Marzouki F, Abdalla S, Al-Almeer S. Dye sensitized solar cells with low cost carbon nanotubes electrodes. Advances in Material Science and Engineering 2016; 4928710: 1-13. https://doi.org/10.1155/2016/4928710

[19] Otakwa R, Simiyu J, Waita S, Mwabora J. Application of dyesensitized solar cell technology in the tropics: effects of radiation intensity and temperature on DSSC performance. International Journal of Advanced Renewable Energy Research 2012; 1(2(4)): 17-25.

[20] Wajir County Government. First county integrated development plan 2013-2017. Nairobi: Republic of Kenya 2013.

[21] KNBS. The 2009 population and housing census. Nairobi: Kenya National Bureau of Statistics 2010.
[22] Vihiga County Government. First County Integrated Development Plan 2013-2017. Nairobi: Republic of Kenya 2013.

[23] Kitui County Government. County integrated development plan 2013-2017. Nairobi: Republic of Kenya 2014.

[24] Kajiado County Government. First county integrated development plan 2013-2017. Nairobi: Republic of Kenya 2013.

[25] Otakwa R. Dye sensitized technology in Kenya. Saarbrucken, Germany: LAP LAMBERT Academic Publishing 2017.

[26] Lobato K, Peter L. Direct measurement of the temperature coefficient of the electron quasi-fermi level in dye-sensitized nanocrystalline solar cells using a Titanium sensor electrode. Journal of Physical Chemistry B 2006; 110(43): 2190-2192. https://doi.org/10.1021/jp0645380

[27] Bergine $M$, Krašovec $U$, Hočevar $M$, Topič M. Performance of DSSCs based on ionic liquids: Effect of temperature and iodine concentration. Thin Solid Films 2008; 516: 7155-7159. https://doi.org/10.1016/j.tsf.2007.12.003

[28] Roux L. The effects of reverse bias on the efficiency of dye solar cells. Western Cape: Department of Physics, University of Western Cape 2009.

[29] Sauvage F, Decopet J, Zhang M, Zakeeruddin S, Comte P, Nazeeruddin M. Effect of sensitizer adsorption temperature on the performance of dye sensitized solar cells. Journal of the American Society 2011; 133(24): 9304-9310. https://doi.org/10.1021/ja110541t 